Issue no. $26 / 2018$

\title{
THE FUTURE OF THE NORMATIVE POWER EUROPE CONCEPT FROM THE VISEGRAD GROUP'S PERSPECTIVE
}

\author{
Dr. Anna Skolimowska \\ Institute of Political Science \\ Cardinal Stefan Wyszyński University in Warsaw \\ skolimowska.anna@gmail.com
}

DOI:10.24193/OJMNE.2018.26.09

\begin{abstract}
The European Union (EU) is becoming an independent actor of International Relations. Its external activities are diverse: ranging from economic relations (mainly through the Common Commercial Policy or association agreements) to the Common Foreign and Security Policy (CFSP). Also, the geographical scope of its presence is wide - from the nearest neighborhood in the European continent to the countries of Africa, Far East or South America. For this reason, in the academic as well as in the public discourse, questions are posed on the EU's role in international relations. One of the leading concepts is an idea of the European Union as a normative power (Normative Power Europe, NPE). This article will analyze the status quo and future of the NPE concept among Visegrad countries expressed in the discourse of their political elites in: Poland, Hungary, the Czech Republic and Slovakia. It is assumed that the changing nature of the international reality in recent years, i.e. the Russian-Ukrainian conflict and the migration crisis undermined the dominant narration about the EU in International Relations as a Normative Power and led to new forms of expression of its international identity. Political discourse in the new member states of the EU will be analyzed in searching for an answer to the question: what is the perception of the NPE in the selected Central European countries?
\end{abstract}

Keywords: Normative Power Europe concept, Common Foreign and Security Policy, global strategy in foreign relations, Visegrad countries

\section{Introduction}

The Lisbon Treaty provisions, which became effective in December 2009, changed the European Union’s character in International Relations (IR) ${ }^{\ddagger \neq}$. The Treaty ended the discussion on the EU's international status. The European Union, since the Maastricht Treaty

抹 Treaty of Lisbon amending the Treaty on European Union and the Treaty establishing the European Community, signed in Lisbon, 13 December 2007. 
(1993), had not had a legal personality and could not act in IR as a single player. Due to the lack of legal personality, the Union's status in IR was unclear and did not allow it to undertake many external activities. On the basis of the Lisbon Treaty provisions (article 47 of the Treaty on European Union), the international status of the European Union became clearer. It was given a legal personality that facilitates the relations with the external environment. In addition, the organizational system of the European Union based on three pillars disappeared. However, it has been noted that this change is only formal (Skolimowska, 2014, p. 140). As part of the former first pillar, the community method of decision-making still applies (implemented mostly within the ordinary legislative procedure, with a strong role of the European Commission, the Council and the European Parliament, decisions are made in a large number of cases by qualified majority voting). Such a formula still refers to the economic aspect of the European Union's external relations (Treaty on the Functioning of the European Union, 2009, Articles 288-294).

With regard to the Common Foreign and Security Policy, its specificity in terms of the method of decision-making and its nature has been preserved. The role of supranational institutions, such as the Commission and the Court of Justice or the European Parliament, is small here. The intergovernmental nature of cooperation in the field of political external relations of the European Union has also been preserved. In the field of the CFSP, it is subject to specific rules and procedures, which is expressed in the fact that decisions in this area are taken essentially unanimously (Treaty on European Union, Articles 21-46).

The legal changes of the EU's character in international relations introduced by the Lisbon reform were not the only elements of the discussion on the European Union's external activity. Parallel to the debate on the legal issues, there is a public as well as an academic debate about the nature of the EU's role and identity in the international arena. Scholars and politicians seek to develop theoretical approaches and political strategies that would correspond to the specificity of the European Union in the international space. One such theoretical proposal is the concept of Normative Power Europe (NPE) worked out by Ian Manners in 2002.

This article will examine the character, origins and evolution of the Normative Power Europe (NPE) concept form the perspective of Visegrad countries: Poland, the Czech Republic, Slovakia and Hungary. It is assumed that new Central European countries do not 
share the idea of the European Union as an actor whose only power is connected to the norms and values spread outside its borders. They tend to share a more realistic and pragmatic attitude towards the EU's character in international relations, rooted in its power of economic and military capabilities.

This study is divided into three parts. The first part will seek to answer the question about the nature of Europe's international presence, challenges for CFSP, as well as opportunities on the global arena. In the second part of the article the nature of the Normative Power Europe concept, its origins and status quo will be evaluated. The aim will be to find out whether the political actors of the EU share the idea of the normative character of the EU in IR. The third part offers an analysis of the Central European countries' attitude towards the EU’s identity in International Relations.

\section{The changing nature of the European Union in International Relations}

The European Union appeared on the map of International Relation in 1993, when the Treaty of Maastricht provisions came into force (Treaty on European Union, 1992). According to the Treaty: "The Union shall be founded on the European Communities, supplemented by the policies and forms of cooperation established by this Treaty. Its task shall be to organize, in a manner demonstrating consistency and solidarity, relations between the Member States and between their peoples” (Treaty on European Union, 1992, Art. A). One of the elements of the newly-created institution was an integration of foreign and 
security affairs within the framework of the Common Foreign and Security Policy §§§ (Treaty on European Union, 1992, Title V).

However, the Maastricht Treaty did not give the EU a legal personality. Since 2009, when the Treaty of Lisbon provisions came into force, the formal and legal status of the European Union in international relations has not been clear. Before that time, legal experts pointed that: “The European Union is a specific international structure of a sui generis character, without legal personality, operating on the basis of an international agreement (TEU) and being in a state of development (in statu nascendi)” (Barcz, 2011, p. 28). Then, the European Union derived from the legal personality of the European Communities in international relations. The illustration of this situation was its pillar structure. This situation changed with the implementation of the provisions of the Treaty of Lisbon, under which the European Union gained a legal personality (Treaty on European Union, 2007, Art. 47).

As a result, the European Union has received the characteristics of an international organization. The consequence of this decision is the abolition of the Union's pillar structure, the unification of the decision-making process and a catalogue of legal instruments. The decision to transform the Union into an international organization also entails important political implications for the perception of the Union's legal nature. In this way it is explained that the process of the European integration takes the legal form of an international organization - created by states under an international agreement, in which the competences

\footnotetext{
$\S \S$ According to Title V of the Maastricht Treaty: "The objectives of the common foreign and security policy shall be to safeguard the common values, fundamental interests and independence of the Union; to strengthen the security of the Union and its Member States in all ways; to preserve peace and strengthen international security, in accordance with the principles of the United Nations Charter as well as the principles of the Helsinki Final Act and the objectives of the Paris Charter; to promote international cooperation; to develop and consolidate democracy and the rule of law, and respect for human rights and fundamental freedoms. The Union shall pursue these objectives: by establishing systematic cooperation between Member States in the conduct of policy, in accordance with Article J.2; by gradually implementing, in accordance with Article J.3, joint action in the areas in which the Member States have important interests in common. The Member States shall support the Union's external and security policy actively and unreservedly in a spirit of loyalty and mutual solidarity. They shall refrain from any action which is contrary to the interests of the Union or likely to impair its effectiveness as a cohesive force in international relations. The Council shall ensure that these principles are complied with.”
} 
and structure of this organization are defined. This should put an end to the fears that this process is moving towards some form of a pan-European state at the expense of the sovereignty of the member states.

On the other hand, it should be remembered that cooperation between states within the European Union goes far beyond the formula of an international organization. However, the single currency, specific political system being the subject of the analysis of researchers dealing with political systems of states, the category of European citizenship, universal elections to the European Parliament and finally the decision system in the European Union are those elements of the EU's construction that move it away from the category of classical international organization, even after the Lisbon reform.

Since 1993, despite a complicated and sometimes confusing system of the European Union's integration model, it has been becoming a more visible and important actor of international relations. The European Union has been seeking its place on the global stage. It is present in international relations through: external economic relations (within the framework of the Common Commercial Policy, rendered development assistance, cooperation with third countries, humanitarian aid etc.) and the Common Foreign and Security Policy (CFSP). Both of these dimensions make up the concept of its external relations. Institutionally, this area of European integration has a twofold character, which results from the existence of two decision logics in it: communitarian/supranational (for economic cooperation) and intergovernmental (for cooperation under the CFSP). Although the Treaty of Lisbon unified the structure of the European Union by eliminating its pillar structure - which is an expression of the above logic - in relation to external relations, its specificity has been preserved. Integration in the scope of CFSP has a different organizational and decision-making framework than in the context of economic relations. Making decisions here is in the nature of agreements and compromises between member states, and is not done at the level of the European institutions, independently of them. The European Union's role in foreign affairs is to: coordinate the positions of member states and establish strategies and an agenda for joint action. This area of European integration consists of the cooperation of sovereign member states in foreign matters, which is expressed by keeping unanimity as the main method of making decisions and limiting the role of supranational institutions (Treaty on European Union, 2009, Title V). 
Issue no. 26/2018

An important element of the external relations of the European Union are also the activities undertaken by member states as part of national foreign policies. In accordance with the provisions of the Treaty of Lisbon, cooperation in the field of foreign affairs between member states has an intergovernmental character and is not in conflict with national foreign policies. The space of communication, negotiation and deliberation is occupied by institutions in which the member states coordinate their foreign policies and strive to develop a common European position. These include: the European Council and the Council of the European Union. The implementation of the adopted arrangements rests on the shoulders of the High Representative for Foreign Affairs and Security Policy, the President of the European Council and the member states.

Based on the above claims regarding the specific nature of the European Union's external relations, it can be noted that they differ from the national foreign policy model. Activities in the European Union forum (in particular under the CFSP) involve the coordination, negotiation and determination of joint strategies, positions and actions by the Member States.

The changes introduced by the Lisbon Treaty in the institutional structure under the CFSP are: strengthening the European Council by granting it the status of an EU institution and equipping it with the possibility of issuing binding acts (decisions); the separation and creation of two distinct configurations within the Council of the European Union: the General Affairs Council and the Foreign Affairs Council. This exercise was aimed at distinguishing foreign issues from the current matters of European integration; the establishment of the institution of the High Representative of the Union for Foreign Affairs and Security Policy (Article $18 \mathrm{TEU}$ ). He is appointed to this position by the European Council (acting by qualified majority) with the consent of the President of the Commission. The High Representative leads the CFSP (the new office combined the tasks of two former institutions: the High Representative for the Common Foreign and Security Policy and the Commissioner for External Relations). He contributes, through his proposals, to the development of CFSP and implements it, acting on the authority of the Council. This also applies to the Common Security and Defence Policy. The High Representative is also the Vice-President of the European Commission (his responsibilities concern the field of external relations and he coordinates its policies in this matter) and presides over the Foreign Affairs Council (ensures 
coherence and continuity of work in the field of EU foreign policy). One should also mention the creation of the European External Action Service, which supports the work of the High Representative. The body cooperates with the diplomatic services of the member states and consists of officials from the relevant services of the General Secretariat of the Council and the Commission, as well as the personnel seconded by national diplomatic services. It started functioning on January 1, 2011. The office of the permanent President of the European Council was also created and equipped with the competence to conduct external activities. He is responsible for the preparation and continuity of the work of the European Council, in cooperation with the President of the Commission and on the basis of the work of the General Affairs Council. The activities of EU bodies in the field of external activities are supported by such institutions as: COREPER, the Political and Security Committee, the European Defence Agency and the European Union Satellite Centre.

The role of the European Commission in the field of the CFSP is defined by the Treaties. The Court of Justice of the European Union is not competent in this matter, with the exception of jurisdiction to control compliance with the legality of certain decisions. The role of the European Parliament in the field of external relations has been strengthened by, inter alia, the ability to address questions or formulate recommendations to the Council and the High Representative. Twice a year, it conducts a debate on the progress of the CFSP, including a common security and defence policy.

The European Union has indeed been seeking its own identity in International Relations. In 2003, the first of the political documents containing the self-definition of the European Union's identity in international relations was prepared (European Security Strategy, 2003). This document contains an indication of the civil and normative nature of European identity. It emphasizes the challenges for European security, such as: terrorism, the availability of weapons of mass destruction, organized crime, the weakening of the state system and the privatization of armed forces. Europe's response to these challenges was to increase the potential to mobilize all necessary civilian resources in crisis and post-crisis situations. It was mainly about (soft) civilian instruments such as: increasing diplomatic capabilities, better exchange of intelligence information between Member States and partners, increasing the number of civilian missions or strengthening the EU's operational capabilities within NATO in the field of crisis management. The strategy assumed cooperation with 
neighbouring countries in the field of the democratization process and economic issues. The document also contains an indication of the reference to international law and the United Nations system as guarantors of the order of the former.

The European Security Strategy of 2003, however, did not respond either to the content or to the form of the challenges and threats faced by the European Union and its members. In 2015, the European Council entrusted the High Representative with the task of developing a new global EU strategy in the field of foreign and security policy. It was determined that member states should expect such a document by June 2016. Many entities took part in the inauguration process where reflection on the directions and assumptions of the new global strategy of the European Union was made. Not only European institutions (including the European Parliament), national parliaments, expert circles (from Poland there was, inter alia, the Polish Institute of International Affairs), but also civil societies took part in it.

The effect of this process was the development and presentation of the assumptions of the global EU strategy in the field of foreign and security policy in June 2016. The new document entitled: Common vision, joint action: A stronger Europe. The global strategy for the foreign and security policy of the European Union includes the assumptions of the new global strategy of the European Union in international relations: "The strategy is to express the ambition of the strategic autonomy of the European Union. We live in times of existential crisis, both within the European Union and outside it. Our Union is at risk. Our European project, which brought unprecedented peace, prosperity and democracy, is now being questioned. In the east, the European security order has been violated, and terrorism and violence are afflicting North Africa and the Middle East, as well as Europe itself. Growth is not keeping pace with demographic change, security tensions in Asia are getting worse and climate change is causing further distortions”.

Analysing the philosophy of the new strategic assumptions of the European Union in international relations, one can point to the evolution of views on the role of the EU in the world and the emergence of reflections on the need to develop real instruments of international influence. This evolution, also in relation to the Strategy from 2003, is expressed in the departure from the idealistic vision of the international environment and the 
role that the European Union should play in it. Until now it was a role that could be described as a normative actor.

Meanwhile, the new strategic document from 2016 draws our attention to the concept of 'principled pragmatism' as a philosophy of EU external relations. It means that the actions of the European Union in the international environment will result from a realistic assessment of the environment, to which it will respond with more adequate external policy instruments than hitherto. The document focuses not so much on instruments of soft international influence, such as: economic instruments, promotion of democracy, human rights, institutionalization of cooperation, but clearly emphasizes the need to authenticate the EU's position in external relations by means of military external policy instruments: "The priority issue is investing in security and defence in particular. In order to be able to respond to external crises, build the potential of our partners and guarantee the security of Europe, a full spectrum of defence capabilities is necessary'.

The strategy devotes much space to issues related to the need to strengthen the European defence dimension and build independent forces capable of defending and guaranteeing European interests in the world. There are numerous references to the idea of multilateralism and the reform of global governance proposal for the area, which could compete, for example, with the Russian offer.

\section{The Normative Power Concept - theoretical findings}

The unclear character of the European Union in international relations since the Treaty of Maastricht has resulted in seeking appropriate tools and paradigms to describe its presence in global affairs. One of the popular concepts was an idea that the European Unions' uniqueness is its strength in the relations with third parties. There was an idea of Normative Power Europe (NPE) developed by Ian Manners in 2002 to describe the European Union's role in international relations (Manners, 2002). It was assumed that normative power refers to the European Union's ability to spread the norms and standards of European integration respect for human dignity, liberty, democracy, equality, the rule of law, and respect for human rights (Treaty on European Union, 2009, Art. 21) as well as the legal, economic, social, political, and cultural norms elaborated during the European integration process. 
Issue no. 26/2018

The analysis of the role of the European Union in international relations according to Manners' concept of normative power was supposed to leave behind the formal analysis of institutions or external policies of the EU in international relations, and to focus instead on the approaches within a sociological or cognitive framework. Manners claimed that the phenomenon of normative power should be understood as the ability of one international entity to exert its ideological influence on other members in international relations (described by the notions of 'power over opinion' and 'ideological power ${ }^{* * *}$ ). Therefore, the concept itself is not founded on the analysis of the economic resources held by the EU in international relations. It rather refers to its ability to diffuse European legal and political standards, ideas, discourses and integration standards, and to shape the international environment with the use of such tools. The catalogue of norms includes all the legal, economic, social, political and cultural norms established in the course of European integration, as well as the norms featured in the Charter of the United Nations, Final Act of the Conference on Security and Cooperation in Europe (Helsinki Final Act), Charter of Paris, Universal Declaration of Human Rights, and in other documents. The normative presence of the European Union in international relations should lead to a change in the norms, standards and principles of international politics. The innovative and original character of the concept of the European Union as a normative power was built on the assumption that the power of the EU in International Relations does not lie in its military capabilities or economic resources, but stems from the importance of the ideas, standards and values underlying the project of European integration (Skolimowska, 2015).

\footnotetext{
${ }^{* * * *}$ At this point, Ian Manners referred to Johan Galtung's idea of ideological power of the European Communities developed in 1973 (Galtung, 1973).
} 
Ian Manners emphasized that the European Union constitutes neither a civilian power $^{\dagger+\dagger \dagger}$, nor a military power; instead, it possesses the features of a normative power built on the founding principles of the European project. The normative power of the EU lies in exporting the systems of norms (or: the normative system), as described above. This occurs through: spontaneous diffusion - the European Union's norms are naturally diffused in third states without the EU's engagement or activity; the use of communication strategies - the informational activity of the EU; procedural activities - the institutionalization of relations with the EU; transference of mutual benefits in the relations of the European Union with third states; the presence of the EU in third states; cultural diffusion and the process of learning European norms by third states (Manners, 2002, p. 254).

Normative power is also related to the European Union's ability to exert influence on the external environment not merely by the use of economic instruments (as in the case of a 'civilian power'), but rather by the attractiveness of the European project to third parties. Once third parties recognize European values as attractive and convincing, mutual relations between the entities become institutionalized and a political dialogue concerning the conditions of co-operation between them is established. The European Union thus acts and promotes its values through its policies, for instance through development aid and assistance, through trade, enlargement policies etc. Yet, it is still the political dialogue with the third parties that remains the most important channel for transferring the European norms and values. This dialogue, however, needs to be institutionalized, for example in the form of

t+t+ The concept of civilian power was developed in 1972 by François Duchêne. The author claimed that the power of the European Communities in IR was founded not on their military force, but rather on their common market and political instruments, which enabled the Communities to construct their areas of influence in the world. The notion of 'civilian power' refers to those international entities whose foreign policy consists of, for example: accepting the necessity of co-operation with other participants in the international forum (i.e. the idea of multilateralism); using non-military instruments (mostly economic instruments) to secure the states' individual interests; and being ready to create or to enter into supranational structures in order to resolve current issues. A foreign policy of a 'civilian power' is constructed via the use of economic, diplomatic and cultural measures, as opposed to the use of military power. F. Duchêne additionally noted that Western Europe, in its role as a civilian actor, was greatly contributing to international politics and helping to eliminate the risk of military conflicts by focusing on the necessity of economic, social and cultural co-operation. 
association agreements, the European Neighbourhood Policy, or strategic partnerships, and accompanied by the socialization process of its participants (Manners, 2002, p. 241) for reasons of accepting or rejecting the EU as a normative power by the third states.

Ian Manners' concepts of Normative Power Europe has become popular among scholars of International Relations and European Studies. It was also influential among political elites and gave a theoretical background to constructing political strategies of the EU in IR, in 2003 (European Security Strategy, 2003).

There are scholars who express their concern when it comes to the thesis on the normative character of European power in International Relations. Thomas Diez is of the opinion that the concept of a normative power has become an important subject of discussion in the field of European studies. However, a number of significant questions related thereto give rise to controversies (Diez, 2015, p. 635). One of them is the issue of dichotomy: the particular interests of the member states versus collective European norms in external relations. This particular issue has seemed quite visible, for example, in relation to the attitude adopted by the EU towards the democratic movements in several Arab states (referred to as 'the Arab Spring'). On the one hand, the European Union declared that it would take an active part in building democracy in the region; while on the other, it supported authoritarian regimes in order to stop the wave of migrants crossing the Mediterranean Sea and to secure petroleum supplies coming to Europe. It remains to be established whether the EU as a normative power constitutes an effective actor in International Relations; that is, whether the European norms truly influence the behaviour of third states. When researched, this question presents a number of difficulties, as the EU is usually but one of the actors in the process. It is equally difficult to provide conclusive and unambiguous proof that, at a given moment, it was the European norms that most influenced the course of events. The issue concerns the level of analysis of the normative power of the EU. In the light of the fact that the supra-national integration model for external affairs has not yet been established, the research into this matter must encompass a number of actors taking part in the process; this concerns both the Member States and private actors, such as European companies involved in weapons trade (Diez, 2011, p. 2).

Kalypso Nicolaïdis and Robert Howse state that the image of the EU's role in international relations is created by the EU itself and does not reflect its actual role, rather 
constituting an image of the ideal that Europe wishes to attain (Nicolaïdis, Howse, 2002, p. 768): This means that the European Union does not truly export its normative offer, but rather a certain representation of what the EU wishes to be. The authors of this concept refer to it as 'EUtopia', i.e. a utopia that the European Union has created about itself. Hence, the international activity of the EU constitutes a form of projection or a presentation of the myth that Europe is a community of norms and values. This particular strategy is based on the assumption that the EU is indeed a role-model for the rest of the world and that it sets an example to be followed. This attitude can be seen, for instance, in the European support for regional forms of integration in various parts of the world, such as the African Union. However, as pointed out by Nicolaïdis and Howse, the true identity of the EU and the image that it wishes to create in international relations are not consistent, which, in turn, decreases its credibility in the eyes of the international public.

Despite some challenges, the concept of normative power, developed mainly by Constructivists in the area of European studies, may constitute an important contribution to the debate on the nature and specificity of contemporary powers in International Relations. The analysis of the European Union's case shows a different example of the specificity of power than we have observed so far (mostly a material one), offering the view of the cultural, ideological and identity aspects of this phenomenon; this does not mean, though, that Constructivists aim to develop a concept of power that would be competitive to that offered by rationalist theories. Representatives of this paradigm advocate the need for a broader analytical approach to the power phenomenon which will reflect its non-material, more ideological and social face. Constructivists perceive power in ideation categories, as constituted more by ideas than material forces and conditioned by the cultural context of the international system (Wendt, 2008, p. 97). The importance of power in international relations changes along with the current distribution of interests and their content. This means that power depends on the interpretation and significance attributed to it by countries. It is assumed here that ideas not only have significance in International Relations, but also constitute the material base of this reality, giving it sense and significance. In the Constructivist approach, the current materialistic interpretation of power is being replaced by the ideation and the normative and discursive approach. Based on the Constructivist assumption that the action of the state in international relations stems from the interpretation 
of facts, we might also say that the specificity of power is connected with the subjective meanings given to it by other participants in International Relations.

To sum up, there are a few deficits of the Normative Power Europe concept. First, there is a need to develop more precise statements and take into account the evolving role of the material factor in the European Union's external policy. Second, the academic concept of the European Union's normative power is strongly correlated with the EU's own definition of identity, appearing in programming documents concerning its external relations. I have observed here the danger of a subjective theoretical position developed for the needs of a scientific legitimization of the EU's normative power, instead of an objective analysis and explanation. Third, the concept of the European Union's normative power is rather poor, as it focuses only on one aspect of the EU's power in international relations (the aspects of norms and European values). Moreover, it is difficult to demonstrate the relationship between the EU's normative power and its influence on international politics. Some scholars even claim that the concept of normative power was falsified in the research on the international role of the European Union (Toje, 2009, p. 49). It seems to have low potential to explain the EU's role in International Relations compared to such concepts as rational choice or the game theory on the analysis of norms, values and identity on the international system level and the importance of ideation ontology as a vital factor affecting political preferences of states (not only internal factors). Many proposed notions, however, are poorly defined.

\section{The Visegrad Group's perspectives on the future of the Normative Power}

\section{Europe concept}

The future of European integration is an important element of public discourse not only among the political elites of the European Union based in Brussels, but also in its member states. Special attention will be paid to the Republic of Poland, the Czech Republic,

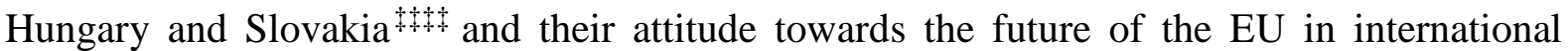
affairs in the light of the Normative Power Europe concept. These are new members of the European Union (2004) with different kinds of challenges when it comes to foreign and security affairs. Proximity to Russia as well as strong ties with the USA and NATO makes

\footnotetext{
执护 Countries that form The Visegrad Group.
} 
them different from old European countries. From this perspective, it is interesting to make an analysis of their attitude towards the future of the CFSP in terms of the Normative Power Europe concept. The Visegrad countries have different views regarding their security. For Poland, it is Russia that remains the main threat, whereas NATO is believed to be the only real protection. Poland is concerned about creating any European structures that might be understood as competitive or even parallel to NATO. Apart from the concerns about creating structures competitive with NATO, Poland is worried about the negative consequences on its arms industry and its ability to compete with Western European factories. Poland, however, ultimately supported the launching of the so-called Permanent Structured Cooperation in Defence (PESCO) at the EU summit in June 2017.

The issue of the arms industry is irrelevant to Slovakia, which does not have such factories. Traditionally not investing in its military forces, Bratislava supports the idea of closer European defence cooperation. In May 2017, Slovakia announced it would increase its military budget to $1.6 \%$ of GDP by 2020 . Russia does not elicit negative emotions among Slovaks.

Similarly, Russia does not raise serious security concerns in the Czech Republic and Hungary, unlike in Poland. However, both countries would rather support integration in the field of defence, due to their desire to remain in the mainstream of the integration process. In Hungary, security is a key watchword for the ruling Fidesz party (security against terrorism, security against refugees), which plays an important role in the party's political narrative (Fuksiewicz, Łada, 2017, pp. 7-8).

The country with the aspiration to become a leader of the Central European region is Poland. It is an active player of both economic integration and the Common Foreign and Security Policy (CFSP). Polish membership of the European Union, in particular of the CFSP, has somewhat weakened the current pro-Atlantic (pro-American) orientation of the country's foreign policy. Membership of the EU has made the EU Common Security and Defence Policy (CSDP) an equally important pillar of Poland's security (involvement in the creation of new battle groups, in the work of the European Defence Agency, and the establishment in 2009 of strategic cooperation with France in matters of security and defence). However, this does not mean the weakening of relations with the US, but only the shift of emphasis in defining the pillars of national security (Milczarek, 2008, p. 50). 
The above issue can be analysed as the effect of Europeanization in the top-down model. The Polish foreign policy operating under the CFSP has adapted to its objectives with regard to security issues. In the second dimension (assuming the bottom-up Europeanization hypothesis), Poland has brought a model of relations with the US to the CFSP system, balancing the role and importance of NATO, while striving to build a European identity in the field of defence. Poland drew the attention of the European Union's member states to the need and even the necessity to have close cooperation with NATO, for example on the occasion of the declaration of support for Georgian and Ukrainian membership plans in this organization, as indicated in the Bucharest Summit Declaration in 2008.

The possibilities of the effective implementation of the above strategy have so far weakened the image of Poland, especially in the eyes of the so-called 'old Europe', as the 'Trojan horse of the USA' (Garkov 2008). For this reason, the idea of Atlanticism, which is clearly present in the doctrine of Polish foreign policy, is often considered a source of deepening differences and divisions in European countries regarding the significance and place of NATO for the European collective security system.

As a member of the European Union, Poland began to engage in initiatives in the field of military integration as part of the Common Security and Defence Policy. In this way, it ceased to be oriented only towards NATO security issues. Poland occupies the fifth place in terms of participation in EU civil and military operations. In addition, strengthening the military capabilities of the European Union has become one of the tasks of the Polish Presidency in the second half of 2011 (Czaputowicz, 2011, p. 34).

At the moment, Polish political elites point at many challenges for the EU's presence in international relations (Polska debata wokót białej księgi, 2017). The Polish debate on European security focuses on new threats: energy, digital and information, still noticing their lower rank than the provision of hard security. However, experts and politicians claim that the biggest challenge for European foreign and security policy is the lack of readiness to fully cooperate among member states because of their divergent interests. Some Polish experts doubt the possibility of developing the common geopolitics of the European Union due to limited confidence among nations. In discussing the global strategy of the EU, we can see the confusion of Europe and the search for an answer to a new position in the world. It has been noticed in Poland that the Union is slowly redefining itself to the role of a normative 
international actor, which means giving up value as the main axis of international action for realism as to its own potential. As a result, Europe wants to launch a wider range of foreign policy instruments - not only soft power, but also hard power (Polska debata wokót biatej księgi, 2017, pp. 26-27).

Within the framework of the Visegrad Group (V4), the countries of the region (Poland, Hungary, Slovakia and the Czech Republic) expressed their willingness to develop the Common Security and Defence Policy (CSDP) and support military integration within the CFSP. In December 2013, V4 prime ministers called for a new impetus for practical cooperation between the EU and NATO, especially in the area of defence planning and development of capabilities. As a first step, the four Visegrad countries decided to build a joint EU Battlegroup, available for rapid deployment in the first semester of 2016 (Lorenz, 2013).

The Hungarian government welcomed the debate on the future of the EU as the best framework to face and tackle both internal and external challenges: "We are pro-Europe politicians, and our goal is for Europe to be stronger. We Hungarians don't think that it is good to have a debate on whether we need more Europe or less Europe. The objective is to have a stronger Europe. Where there is a need for more Europe, there should be more Europe; and where more national competence is needed, we should let the Member States do their job (...). We think that in the new, large-scale European plan we must have our own defence force, and in this new, large-scale plan we must not talk about a European Empire, nor a United States of Europe, but an alliance of free nations. Competences must be returned to Member States, where they would be in better hands. This is all possible and viable; the only question is whether the European Union will have the right quality of leadership to achieve these objectives” (Orbán, 2018).

In September 2016, the Czech and Hungarian governments voiced their support for creating a 'joint European army', echoing calls from their EU counterparts. This joint army would constitute protection for Europe after Brexit and the consequently weakened armed forces in Europe, and protection against immigration and terrorism (BBC News, 2016).

There is a strong commitment among Visegrad countries to re-launch the EU's Common Foreign and Security Policy. A weak decision-making centre in Brussels has been hamstrung by often confused decision-making in national capitals. A revamped CFSP would 
Issue no. 26/2018

have a lower but more solid common denominator, filling the gaps in the EU's security and defence posture. In a more hands-on approach towards its neighbourhood, the EU can be a facilitator of conflict resolution and stabilization in the South and a transformative power in the East. Visegrad countries support a stronger and more flexible Common Security and Defence Policy, underpinned with adequate capabilities of rapid and meaningful reaction, and reiterate the importance of a strong and geographically balanced European defence industry (Joint Declaration of the Visegrad Group Prime Ministers, 2016).

\section{Conclusions}

The future of the Normative Power Europe concept among selected Central European member states of the European Union is not a popular way of describing the EU's identity in international affairs. Instead, there is a clear vision of both Europe's international role as well as of the future of the Common Foreign and Security Policy.

Firstly, government representatives of the analysed countries together call for strengthening the intergovernmental character of the integration of foreign and security affairs. It is in line with their declaration on giving member states more responsibility in European integration.

Secondly, the countries of the Central European region call for abandoning the idea of the European Union as any kind of power or empire. They rather insist on the European Union as an economic and political partner for the outside world.

Thirdly, representatives of the countries of the region insist on building and strengthening European military forces and call for stronger ties with NATO. This strategy is pragmatic when it comes to geopolitical conditions (proximity to the Russian area of influence).

Analysing the debate on the future of the CFSP among the countries of the Central European region, we can draw a conclusion that there is no consensus when it comes to the perception of the European Union as a normative actor of international relations. Instead, there is a strong will to change the dominant discourse on the normative character of the EU towards a more pragmatic one and that of an actor relying on military capabilities in the international scene. Such an attitude is visible not only in the Polish efforts to work on the new global strategy of the EU in IR, but also in geopolitical circumstances such as proximity 
to the Russian sphere of influence. From that perspective, it seems obvious that Visegrad countries would be more interested in leaving behind the debate on the normative character of the EU's foreign policy and identity. Instead, these countries prefer a more pragmatic and realistic approach to the CFSP.

\section{BIBLIOGRAPHY:}

- $\quad$ BARCZ, J. (2011), Problem modelu prawnego procesu integracji europejskiej i zarządzania w ramach Unii Europejskiej, in: J. Barcz, M. Górka, A. Wyrozumska (eds.), Instytucje i prawo Unii Europejskiej, Warszawa: Wolters Kluwer Polska.

- $\quad$ BBC News. (2016), Czechs and Hungarians call for EU army amid security worries. BBC News, http://www.bbc.com/news/world-europe-37196802

- $\quad$ CZAPUTOWICZ, J. (2013), Polityka bezpieczeństwa Polski - między samodzielnościa a europeizacja, „Ośrodek Analiz Politycznych UW” 11; http://oapuw.pl/wpcontent/uploads/2013/11/J.Czaputowicz-mi\%C4\%99dzy-samodzielno\%C5\%9Bci\%C4\%85-aeuropeizacj\%C4\%85.pdf (12.04.2015).

- DuCHÊNE François, Europe's Role in World Peace, in: R. Mayne (ed.), Europe Tomorrow: Sixteen Europeans Look Ahead, London 1972, pp.32-47.

- DIEZ, T. (2015), Constructing the Self and Changing Others: Reconsidering Normative Power Europe, Millennium: Journal of International Studies, No. 3 (33)/2015, p. 613-636.

- DIEZ, T. (2011), Normative Power as Hegemony, http://www.euce.org/eusa/2011/papers/7l_thomas.pdf (last visited 23.08.2015).

- $\quad$ European Security Strategy - A Secure Europe in a Better World, 2003, European Council, https://europa.eu/globalstrategy/en/european-security-strategy-secure-europe-better-world.

- $\quad$ European Global Strategy Project, 2013, http://www.iai.it/sites/default/files/egs_report.pdf.

- $\quad$ FUKSIEWICZ A., Łada A. (2017), When two plus two doesn’t equal the Visegrad Group on the future of Europe, Analysys\&Opinions 23/150, p. 7-8.

- GAlTUNG, J. (1973), The European Community: A Superpower in the Making, London: Allen \& Unwin.

- Joint Declaration of the Visegrad Group Prime Ministers, 2016, http://www.visegradgroup.eu/documents/official-statements/joint-declaration-of-the-160609 
- LORENZ W. (2013), Grupa bojowa UE - szansa na przełom we współpracy Grupy Wyszehradzkiej?, Biuletyn PISM 38(1014).

- $\quad$ MANNERS, I. (2002), Normative Power Europe: A Contradiction In Terms?, Journal of Common Market Studies, 40, p. 235-258.

- MILCZAREK D. (2008), Stosunki transatlantyckie w sferze polityki zagranicznej i bezpieczeństwa: kontynuacja czy przełom? Polski punkt widzenia, Studia Europejskie 2: 31-57.

- $\quad$ NicOlaïDis K., Howse R. (2002), This Is My EUtopia ...': Narrative as Power, Journal of Common Market Studies, 4(40), p.767-792.

- $\quad$ ORBÁn Victor, Viktor Orbán’s speech at the Visegrád Group conference ‘The Future of EUROPE', HTTP://WWW.MINISZTERELNOK.HU.

- $\quad$ Polska debata wokót białej księgi w sprawie przyszłości Europy Jakie scenariusze dla Unii Europejskiej?, 2017, Przedstawicielstwo Komisji Europejskiej w Polsce, www.csm.org.pl/pl/inne?download=881:polska-debata-wokol-bialej...w...europy.

- $\quad$ TOJE, A. (2009), Normative Power in Europe after the Post-Cold War, in: A. Gerrits (ed.), Normative Power Europe in a Changing World: A Discussion, http://www.clingendael.nl/sites/default/files/20091200_cesp_paper_gerrits.pdf [accessed on: 22.08.2015].

- $\quad$ Treaty on European Union, OJ C 191, 29.7.1992, http://data.europa.eu/eli/treaty/teu/sign.

- $\quad$ Treaty of Lisbon, amending the Treaty on European Union and the Treaty establishing the European Community, signed at Lisbon, on $13^{\text {th }}$ December 2007, O.J. EU C306 17.12.2007.

- SKOLIMOWSKA, A. (2015), The European Union as a 'Normative Power' in International Relations. Theoretical and empirical challenges, Yearbook of Polish European Studies, 18, pp. 111-131.

- SKOLIMOWSKA, A. (2014), Unia Europejska jako organizacja międzynarodowa, Warszawa, CeDeWu.

- WENDT, A. (2008), Spoleczna teoria stosunków międzynarodowych, Warszawa: Wydawnictwo SCHOLAR. 